\title{
Integrated Environmental Quality Assessment of Jodipan Riverbank, Klojen, Malang
}

\author{
$1^{\text {st }}$ Aisyah Nur Handryant ${ }^{1}, 2^{\text {nd }}$ Sri Harini ${ }^{2}, 3^{\text {rd }}$ Tarranita Kusumadewi ${ }^{1}, 4^{\text {th }}$ Prima \\ Kurniawaty $^{1}$ \\ \{ninkarch@gmail.com ${ }^{1}$,sriharini21@yahoo.co.id², tarranita@gmail.com ${ }^{1}$ \} \\ Architecture Department, Faculty of Science and Technology, University Islamic Negeri Maulana \\ Malik Ibrahim Malang, Indonesia ${ }^{1}$, Mathematics Department, Faculty of Science and Technology, \\ Universitas Islam Negeri Maulana Malik Ibrahim Malang, Indonesia ${ }^{2}$
}

\begin{abstract}
This research aims to assess the environmental quality of Jodipan, Malang through the Comprehensive Assessment System for Built Environment Efficiency (CASBEE) Tools. Jodipan is one of the urban villages in Malang city which stands along in the Brantas riverbanks. It is a high-density settlement with the majority of the population work as a merchant. At 2016, the settlement in Jodipan riverbanks painted colorfully, and it made Jodipan called "Kampung Warna Warni" or Colourful Kampong. Jodipan now became one of the new community-based tourism destinations in Malang and succeeded to attract domestic and international tourist. The existence of this kampong gave a big impact on environmental quality especially river since their communities' activities are very depending on the river. The method based on the triplebottom-line approach that adopts three classifications of sustainable development which are the environment, society, and economy. The result of environmental quality in Jodipan kampong riverbank was 2.1. This score indicates a low value and below the average of the environmental quality standards
\end{abstract}

Keywords: integrated, assessment, quality, riverbank

\section{Introduction}

The Qur'an in the letter of Ar-Ruum verse 41 says, "corruption has appeared on land and in the sea as an outcome of what men's hands have wrought: and so He will let them." According to the narrations of Ibn Abbas and Ikrimah, al-Bahr means lands and cities situated on the banks of rivers. Based on the history, known that the development of the city usually largely started from the river area because the river is a source of human life [1]. Further, the imbalance of ecosystems becomes a global issue which keeps getting attention by several researcher such as by Dean [2], Deudney [3], Al-Mulali [4], and Duong [5], because the negative consequences of the imbalances have spread and increased, both qualitatively and quantitatively. United Nations Environment Programme (UNEP) in its exposition shows some common result that occurs because of the imbalance of nature. Including the data in 2007 that shows that CO2 emissions have risen by one-third since 1987; other is degradation of the quality of ground, decline in quantity and quality of water, biodiversity reduction and human ecological footprint that indicates the increase in consumption compared to bio-capacity [6] 
In line with that, World Commission on Environment and Development (WCED) through "Brundtland Report" in 1987 sparked conception called Sustainable Development. The concept of sustainable development has three focuses which had to move and developed together in the economic, social and environmental field. Sustainable development is aimed to reach economic development for a current generation without harming future generations through the use of local resources and environmental protection to prevent the ecological damage. [7-10] The promotion of sustainable development is a big issue for a human being. Assessment of the sustainability of a city is necessary as a process of evaluation of the development that has occurred to create a better environment in the future. In the construction field, there has been a growing movement towards sustainable construction since the second half of the 1980s, leading to the development of various methods for evaluating the environmental performance of buildings such as BREEAM (Building Research Establishment Environmental Assessment Method) in the UK and LEEDTM (Leadership in Energy \& Environmental Design) in North America [11-12]. These methods have attracted interest around the world.

Indonesia itself already has sustainable assessment namely GREENSHIP published by Green Building Council Indonesia, but it only assesses in building scope [13]. Japan Sustainability Building Consortium published a comprehensive sustainability assessment system namely CASBEE. Research about CASBEE in Indonesia has done by some researchers such as Hiromi who do comparison index calculation using CASBEE and LEEDND model to evaluate the development of universities in Indonesia in 2015 [14]. Other is Dzarilarham who use CASBEE model to evaluating the Building at one of the universities in Indonesia in 2014 [15] and Roychansyah who research related to the evaluation of villages in Indonesia [16]. Based on the results of the above studies it is known that the CASBEE method is a comprehensive method for evaluating sustainable development. CASBEE uses data in the form of numbers and non-numbers that produce values that indicate the comprehensive performance of an environment. This research aims to assess the environmental quality of Jodipan urban village, one of the riverbank area in Malang City. Malang city has been experiencing development from year to year, the population increase up to $1,58 \%$ every year. The increasing of the population has also lead ecosystem degradation caused human interventions towards nature, as well as resulting declining of health standard, decreasing of human comfort and reduction of natural resources [17]. Research on environmental quality assessment in Jodipan has never been done before. Further assessment using CASBEE has also not been found to assess riverbanks, as an area that has a major contribution to decreasing environmental quality. Therefore, this study tries to fill the existing gap. This research will be the first research which assesses the environmental quality comprehensively by CASBEE held in Malang especially Jodipan.

\section{Methods}

This research used the quantitative and qualitative approach. Observation has done on several aspects of environmental quality (Q) according CASBEE Tools. The specific type of CASBEE tools that used in this research is CASBEE-UDe for urban development area. This tools is developed based on the triple bottom lines concept, which is one of the important frameworks for assessment and identification of sustainability, this tool adopts the three classifications of the environment, society, and economy as major items of Q. Triple bottom 
line concept emphasizes the balance between economic growth and social while maintaining environmental balance. Location of research is Jodipan especially in the radius observation $150 \mathrm{~m}$ from the river.

\section{Result and Discussion}

\subsection{An Overview of Jodipan, Malang}

Jodipan is an urban village located in Klojen District. This kampong stands along on the riverbanks with an altitude between 440 - 667 meters above sea level. Because of a high location, the average air temperature recorded in ranges from $23.2^{\circ} \mathrm{C}$ to $24.4^{\circ} \mathrm{C}$. While the maximum temperature reaches $29.2^{\circ} \mathrm{C}$ and the minimum temperature is $19.8^{\circ} \mathrm{C}$. The average air humidity ranges from $78 \%-86 \%$, with maximum humidity of $99 \%$ and a minimum of $45 \%$ and the highest rainfall of 526 millimeters.

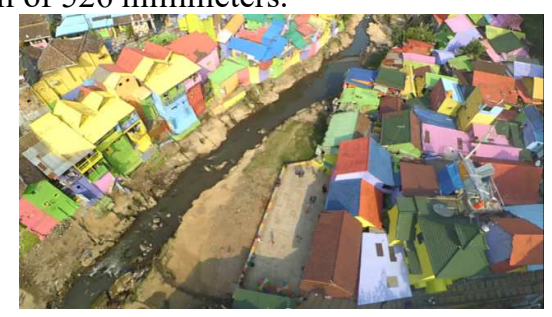

Figure 1. Bird View of Jodipan

Jodipan consists of 8 hamlets and 86 neighborhoods. Regarding the land use, the people in Jodipan urban village still occupy the land with the status of the government of Malang. The local community is very familiar with the existence of the river in their daily activities. Despite that, still found that many people still easily dispose of garbage and waste in the river.

\subsection{An Overview of CASBEE Tools}

Over the past two decades, research has been conducted in several countries to produce a measure of sustainability index measurement in a city such as the UK's Environmental Research Establishment's Environmental Assessment Method (BREEAM), Leadership in Energy and Environmental Design (LEED) in America, Green Mark (Singapore), Green Star (Australia), and Green Building Index (Malaysia). Criterion Planners have mapped out institutions in the world that have conducted assessments related to sustainable development. The assessment divided into areas from wide to small scopes. The wider is such as the Comp Plans for Sustainable Places in America, MEP Eco-City in China, and CASBEE for City in Japan. While the smaller scope is the scope of settlements such as BREEAM Communities in the UK, BEAM Plus Hongkong, GreenMark Singapore, or within the scope buildings such as Green Building Index in Malaysia, and, Green Mark for District in Singapore. 


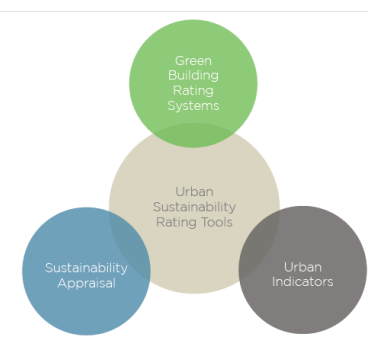

Figure 2. Indicators and Parameters in Urban Sustainability Rating Tools

The tools which use in this research provided by CASBEE. CASBEE is a comprehensive assessment delivered by the Institute for Building Environmental and Energy Conservation (IBEC), Japan. Through CASBEE, the quality of the building assessed by evaluating the building features such as interior comfort and scenic aesthetics, in consideration of environmental practices that include using materials and equipment to create sustainability in using energy or minimize environmental loads. The parameters which used to assess environmental quality in this research described in the table below: 
Table 1. QUD Assessment Items

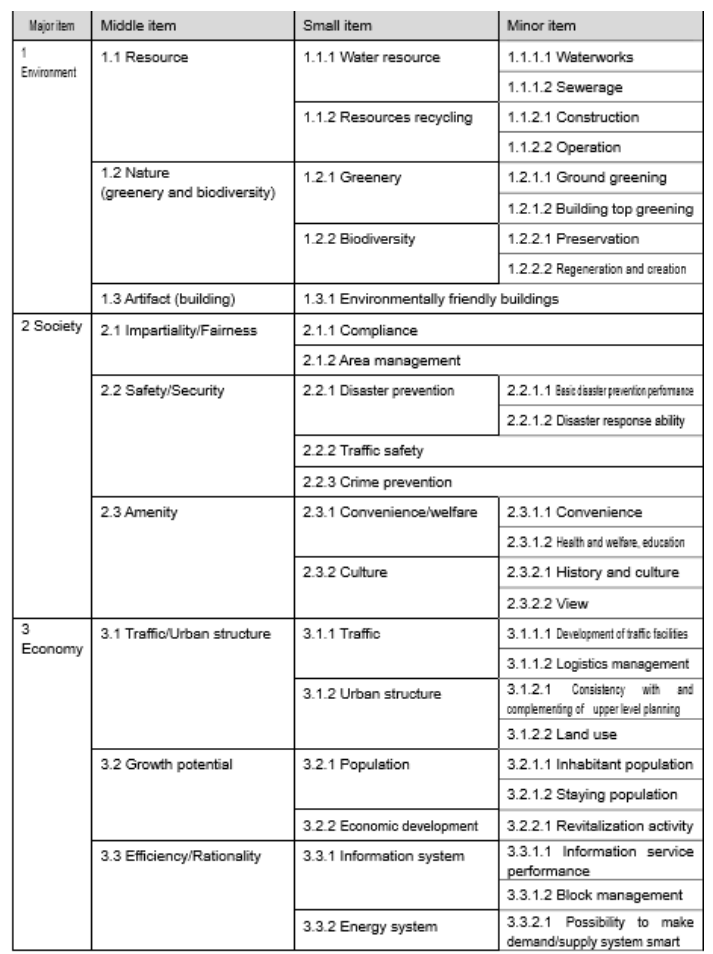

Environmental quality of the assessment object evaluated with the three middle items of resource, nature, and artifact. The first middle item, "resource," contains an actual assessment of efforts for lowering of the environmental load rather than efforts for environmental quality Q. Despite the above, this item is positioned on the Q side because its aspect of "improvement in environmental quality" resulted from efforts, such as water source preservation and establishment of sound recycling-oriented society, being focused. The next item, "nature," evaluates abundance of the natural environment and space in the block/district through matters related to greenery and biodiversity. The last item, "artifact," uses the environmental performance of buildings in the block as a representative index. Specifically, assessment is performed based on the application level of the building/ real estate system of CASBEE tools and their assessment results.

Social quality of assessment object consists of three middle items. The first middle item, "impartiality/fairness," evaluate fulfillment of management that covers not only legal suitability related to the development of the block/district but also harmonization with peripheral local society. The next middle item, "security/safety," evaluate disaster and crime prevention performance of the block/district that directly connected to a sense of safety for residents and visitors and strength and robustness that support the sustainability of the local society. The last middle item, "amenity," evaluates accessibility to various service facilities that contribute to improvement inconvenience, and also evaluates utilization and creation of cultural and historical assets and consideration for the formation of an improved landscape regarding enhancing the value of the area. Last, the assessment of consists of three middle items similar to the classifications of environment and society. The first middle item, 
"traffic/urban structure," evaluate fulfillment of traffic systems that support economic activities and the utilization level of location and site potential regarding urban planning. The next middle item, "growth potential," evaluates the population as a basis for the economic capabilities of the project, and the fulfillment of mechanisms aiming at the revitalization of economic activities. The last middle item, "efficiency/rationality," evaluates fulfillment of services for block users and management related to information and energy

\subsection{The Environment-Socio-Economics Condition of Jodipan, Malang}

An explanation of the environmental, social and economic aspects of this section will explain based on the parameters specified in the CASBEE assessment which are Q1Environment, Q2-Society, and Q3-Economic.

\section{Q1 Environment}

\section{Resource}

Water Resources

The source of the resident's water comes from wells and wells drill. In this urban village, some communities also use Municipal waterworks for the supply of clean water. There is no water treatment system from rainwater and gray water in Jodipan. The location of the observation does not yet have a rainwater utilization system and other water treatment systems. In the case of a reduction in the amount of waste disposal has also not been undertaken either by the construction of a detention pond and rainwater permeable surface and equipment.

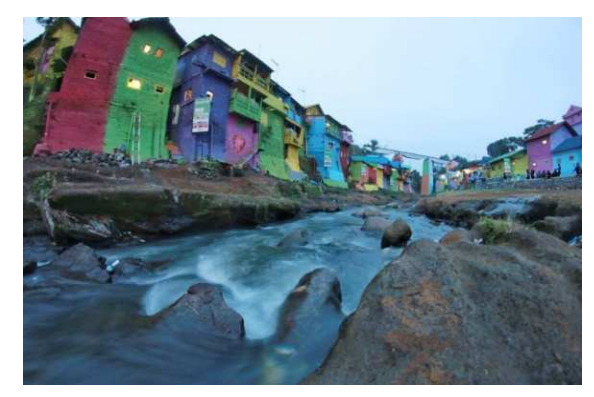

Figure 1. Bird View of Jodipan

A sample test of river water conducted at the observation site. From the sample test results are known that pollution in the water is very high, it had reached $19.83 \mathrm{mg} / \mathrm{L}$ for BOD and $78.20 \mathrm{mg} / \mathrm{L}$ for COD, as described in table 1. below:

Table 2. The Quality of Water of Brantas Watershed at Jodipan

\begin{tabular}{|c|c|c|c|c|}
\hline No & Parameter & Unit & Result & Standard \\
\hline 1 & BOD & $\mathrm{mg} / / \mathrm{L}$ & 19,83 & 0,00 \\
\hline 2 & COD & $\mathrm{Mg} / \mathrm{L}$ & 78,20 & 0,00 \\
\hline
\end{tabular}

This table shows that BOD and COD content exceed clean water standards. It might because residents in Jodipan are uses a liquid waste disposal system conducted on-site through the direct disposal of the septic tank, and most of them are still discharged directly to the Brantas River. 


\section{Resources Recycling}

The use of recycled materials or resources indicates an adequate level. In general, no use of wood material from the sustainable forest. Some roof truss residents use bamboo. Recycled materials such as used tires, used wood also used by residents.

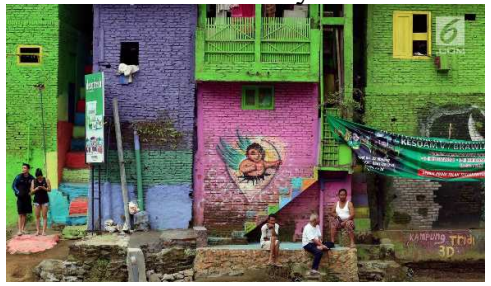

Figure 2. Bamboo as one of material building

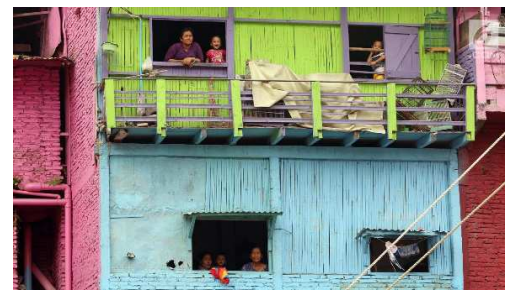

Figure 3. Bamboo as one of material building

Jodipan already available the sort of waste sorting but not functioning yet optimally. No recycling waste processing has found yet.

2. Nature

Greenery

In the area of observation, most of the land use dominated by settlements with densely populated residential conditions. Meanwhile, the percentage of public open space and green open space is less than $20 \%$ compared to the percentage of land built. In Jodipan many settlements of residents are stand on the land owned by Irrigation Agency Malang City. Land use conditions in this area are almost $90 \%$ dominated by settlements with public open space and green open space conditions dominated by massive pavement. Rooftop greening cover less than $15 \%$ of all residents housing and no wall is greened.

\section{Biodiversity}

Natural resources to be preserved are understood by the community, despite that there are no natural resources preserved. Meanwhile, the questionnaire also had spread to know the awareness of the community about sustainable city. Based on the questionnaire result know that the local community is aware of the importance of the concept of sustainability and the role of the river for its survival, but the local community does not evenly share the awareness. Hence, more intensive socialization and education are strongly needed to further increase public awareness of the importance of the concept of sustainable development.

Regeneration and Creation

Score regeneration and creation divided into two aspects; one is from the patch (planar) quality and corridor (network) quality. In the research area, there is no habitat of various species is also established no greening plan being conscious of plant species that originally 
lived in the area (native species) is carried out. The network of species not taken into consideration.

3. Artifact (Building)

Environmentally consideration building

As mentioned before, this research is first research which assesses the sustainability of Jodipan through CASBEE tools, so there is no single building evaluated with CASBEE.

\section{Q2 Society}

\section{Impartiality /Fairness}

Compliance

Based on observation of applicable laws and regulation and verification known that there are many buildings based on a lower standard than the current laws and regulations. Rules on Building Border Lines, River Border Lines and Coefficients of Floor and Height of Buildings are less applied by the residents.

Area Management

In Jodipan there are already local communities that work together with residents that promote residential areas of tourism and river banks. However, promotion related to sustainability and environmental sustainability has not done significantly. A promotion entity and fund for continuous operation of the organization are planned and secured by residents.

2. Security and Safety

Communities know basic disaster prevention, but no hazard map had checked. No item had worked on disaster prevention of various infrastructures. No availability of communication infrastructure about measuring for flood damage prevention, earthquakes, and power disruption for equipment and piping. No water supply or treatment infrastructures like portable water or common facilities for storing water. No energy supply infrastructure likes availability of medium pressure gas supply and connection of electric power and heat supply with the outside area. Regarding disaster prevention vacant space and evacuation route, in the research are there is no appropriate plan regarding the scale and location of vacant space established, the area also not firmed with firebreak belts and no evacuation site in the area.

Traffic Safety

There is no consideration of separating pedestrian and vehicles in the research area.

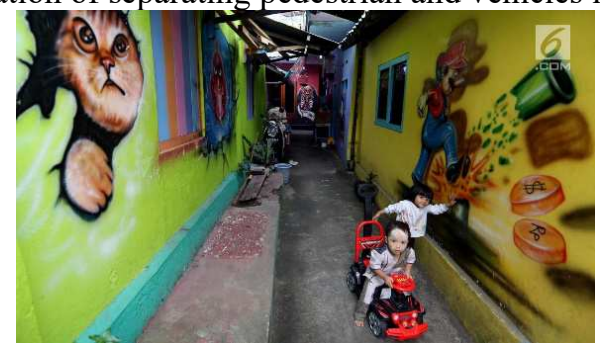

Figure 4. Sirculation Condition in Jodipan

\section{Crime Prevention}

The level of security in the research area is moderate. It can be known by there is no blind spot in the Jodipan, and the area is almost monitorable from the periphery. Night lighting 
sufficiently installed in Jodipan. Meanwhile, the resident had established a manual patrol system to the security guard.

\section{Amenity}

Convenience/welfare

The distance to district facilities and services such as medical and health/welfare facilities (hospital/ clinic, child welfare institution), education facilities (kindergarten, elementary school, and junior high school) and cultural facilities (library, museum, sports facilities) is about $1500 \mathrm{~m}$ or more.

\section{Culture}

Jodipan as a densely populated residential area adjacent to historic areas of Malang City and has made cultural preservation efforts. These efforts, among others, together with the community and the government helped preserve the historic buildings both by maintaining and conserving. The Jodipan residents also involved in preservation effort Malang culture by displaying cultural attributes in Jodipan tourist areas. Many cultural attributes installed in there such as the installation of Malangan mask, Caping (farmer hat) on the corridor of the housing.

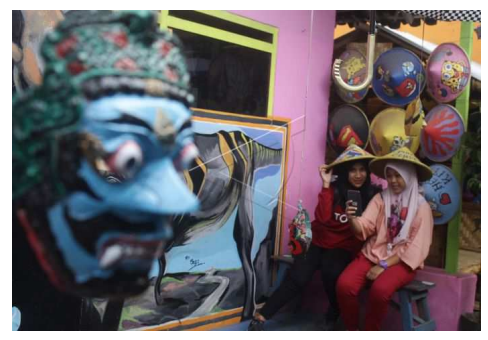

Figure 5. Malangan Mask in Jodipan Corridor

Like an urban village which stands along on the river banks located in the city center, Jodipan by itself creates an interesting view and can be enjoyed directly from the main street of the City. In the development of the area, although there are no particular rules, Jodipan consider its development into the visual city aesthetic, such as the arrangement of wall positions that should not cover each other neighbors, the arrangement of color harmonization between housing, and consideration of appropriate home construction with a human scale.

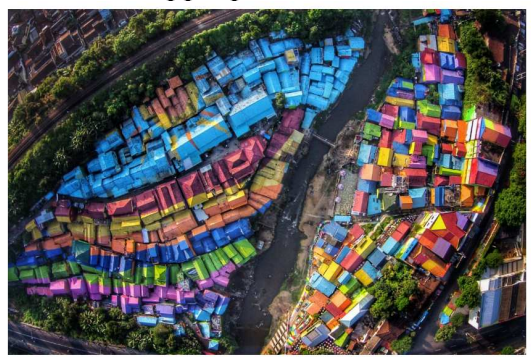

Figure 6. Jodipan and city surrounding

The composition and physical integration of every house in the region ultimately produces a communal identity that does not drown one house's identity with one another. 


\section{Q3 Economy}

1. Trafic and Urban Structure

Traffic

The traffic system in the observation area poorly planned because this area still disputes. Regarding proximity to transportation facilities, the distance to the station is $1 \mathrm{~km}$ or more or to bus stop is $500 \mathrm{~m}$ or more. There is no special circulation path for the loading and unloading activities of large quantities such as for the transportation of garbage from within the area. Usually, the garbage in the settlements of the residents is first collected independently by a special officer from the community themselves to collected in a temporary garbage dump.

Urban Structure

In the research area, consistency with and complementing the upper level not considered. The district designated as an "area for which notification is required upon a change to form or nature." For development, a plan for prevention of diffusion notified, and a measurement based on that take.

2. Growth Potential

\section{Population}

Planned population or actual population is equivalent or higher in comparison to the past state, while the average number of persons staying in each building type is middle between level 1 and level 3

\section{Economic Development}

There is some revitalization activity in this research area such as there is an organization that attracts company advancement and investment to the area exist and cooperative activities with the area are implemented. The company that invests in this village is a paint company that sponsors the coloring of people's homes. The company also participates in financing some activities and other village development such as the construction of a glass bridge connecting Jodipan with the area across the river to another.

3. Efficiency/Rationality

Information System

Regarding information service performance, still, there is no equipment installed in this research area.

Energy System

There is none of the smart technology which applicants in this research area regarding the possibility to make demand/supply smart.

\subsection{CASBEE Assessment of Jodipan, Malang}

An assessment conducted based on observation, interviews and water testing in Jodipan urban villages, Malang. This assessment considers three aspects, i.e., Q1 (environmental quality), Q2 (social condition of society) and Q3 (Economic condition), are described in the table III.

Table 3. Scoring Of Environmental Quality 


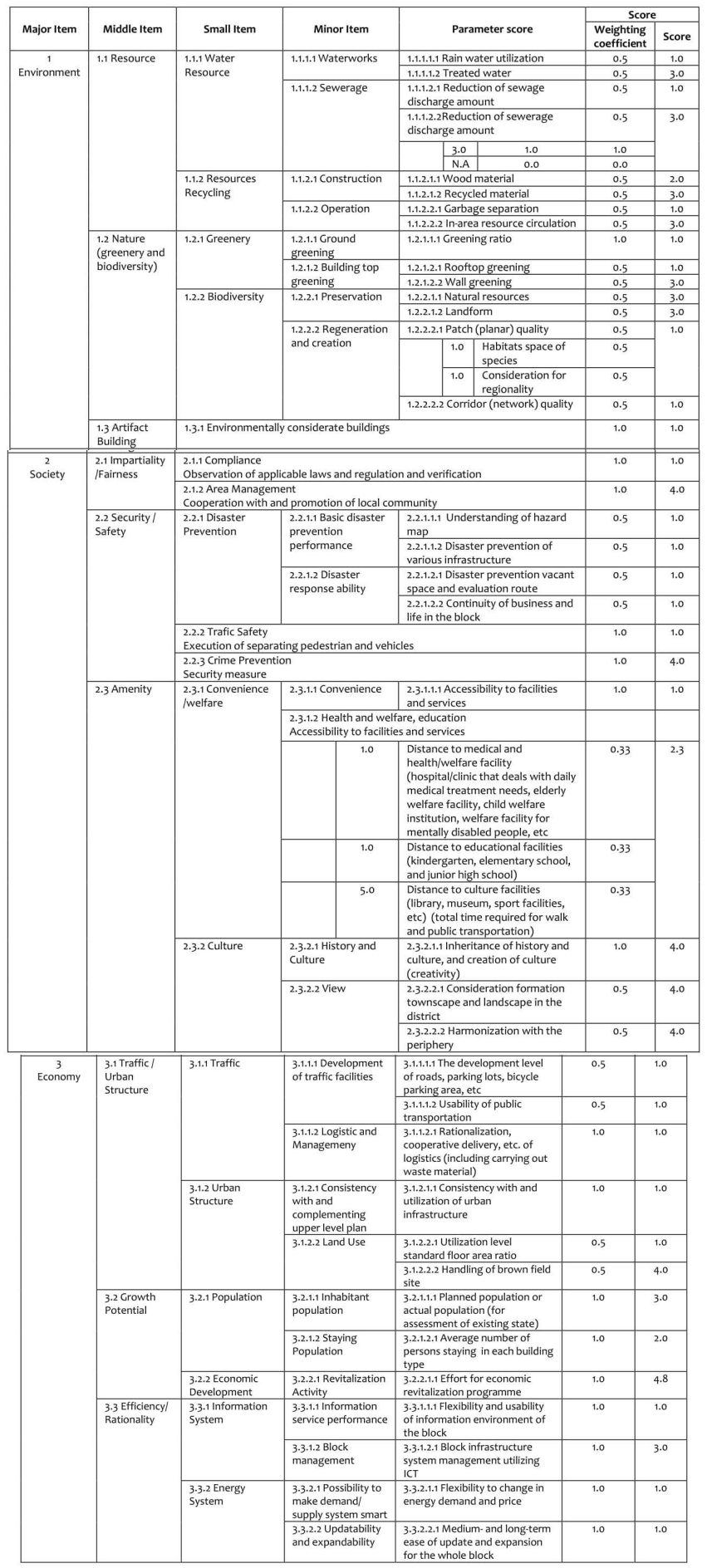


Based on the results of scoring obtained the value of Q1 (environment) total score is 1.8 with detailed aspects of water resource and recycling resources is 2.1 , natural greenery and biodiversity is 1.8, Artifact building environmental friendly is 1.0. Meanwhile, the value of Q2 (society) is 2.4 with details compliance area management is 2.6 , security/safety (disaster prevention, traffic safety, and crime prevention is 2.0 , while aspects amenity which includes welfare, health and education scored are 2.8. Most recently, the economic aspect obtained the value of Q3 (economy) total score is 2.2 with detailed aspect structure the city and traffic flow is 1.4, growth potential (the population and economic development) is 3.7 and efficiency/rationalizing is 1.6. The total score of Q (the quality of the environment) is 2.1. This score indicates a low value and below the average of the environmental quality standards. There are several parameters in sustainable development that have not been or not met in Jodipan. In the environmental aspects, items that cannot fulfill include absence rainwater utilization and treated water, also no effort on the reduction of sewerage discharge amount. Regarding society aspect, Jodipan does not have a strong business regarding basic disaster prevention and disaster respond ability, traffic safety, and crime prevention. While in economic aspects, unfulfilled items are flexibility and usability of information environment of the block, Block infrastructure system management utilizing ICT, and Flexibility to change in energy demand and price.

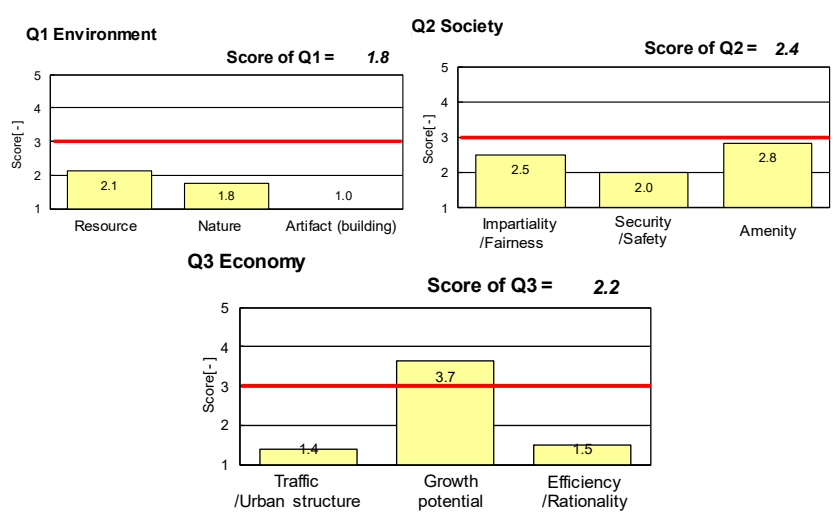

Figure 7. Result of Environmental Quality Assessments of Jodipan

\section{Conclusion}

The total score of $\mathrm{Q}$ (the quality of the environment) in Jodipan is 2.1. This score indicates a low value and below the average of the environmental quality standards. To increase environmental quality need stakeholders involving from the variously related institution. Based on the parameters of CASBEE the urgent items prioritized to improve the quality of the environment in Jodipan are aspects of resource management and management, waste and waste management, community protection and security, understanding and prevention of natural disasters. Further research on environmental load calculation is needed to find out the Jodipan area sustainability index. 
Acknowledgements. This paper in conjuction with the International Conference On Green Technology (ICGT) 2018

\section{References}

[1] I. Katsir, Tafsir Ibnu Katsir. Jakarta: Pustaka Imam Asy'Syafi'i, 2008.

[2] Dean, Thomas J.; MCMULLEN, Jeffery S, Toward a theory of sustainable entrepreneurship: Reducing environmental degradation through entrepreneurial action, Journal of business venturing, 2007, 22.1: 50-76.

[3] Deudney, Daniel, The case against linking environmental degradation and national security, Millennium, 1990, 19.3: 461-476.

[4] Al-Mulali, Usama; Ozturk, Ilhan, The effect of energy consumption, urbanization, trade openness, industrial output, and the political stability on the environmental degradation in the MENA (Middle East and North African) region, Energy, 2015, 84: 382-389.

[5] Duong, Thao; Hultberg, Patrik T, Trade Openness, Economic Growth, and Environmental Degradation in Asian Developing Countries, Journal of Applied Business \& Economics, 2018, 20.5.

[6] Rucevska, Ieva, et al, Waste Crime-Waste Risks: Gaps in Meeting the Global Waste Challenge, A UNEP Rapid Response Assessment, 2017.

[7] Kates, Robert W, What is sustainable development?. 2018.

[8] Wheeler, Stephen M.; Beatley, Timothy (ed.), Sustainable urban development reader. Routledge, 2014.

[9] Sauve, Sébastien; Bernard, Sophie; Sloan, Pamela, Environmental sciences, sustainable development and circular economy: Alternative concepts for trans-disciplinary research, Environmental Development, 2016, 17: 48-56.

[10] Fukuda-Parr, Sakiko, From the Millennium Development Goals to the Sustainable Development Goals: shifts in purpose, concept, and politics of global goal setting for development. Gender \& Development, 2016, 24.1: 43-52.

[11] U. S. G. B. Council, LEED for Neighborhood Development Rating System: Pilot Version. Washington D.C.: USGBC.

[12] Seinre, Erkki; Kurnitski, Jarek; Voll, Hendrik. Building sustainability objective assessment in Estonian context and a comparative evaluation with LEED and BREEAM. Building and Environment, 2014, 82: 110-120.

[13] G. B. C. Indonesia, Greenship Rating Tools untuk Rumah Tinggal Versi 1.0. Jakarta: Direktorat Pengembangan Perangkat Penilaian, 2014.

[14] Hiromi, Rahma; Sakai, Takeru; Divigalpitiya, Prasanna. Comparative Study of New Campus Development in Indonesia.

[15] Dzarilarham, Shohibu; Ridwan, Eng M. Kholid; Alfata, Muhammad Nur Fajri, Evaluasi gedung Grha Wiksa praniti menggunakan metode penilaian sistem rating bangunan hijau comprehensive assessment system for built environment efficiency, 2014, PhD Thesis. Universitas Gadjah Mada.

[16] A. D. Roychansyah, M. S, "Kampung Oriented Development Model: A Rapid Appraisal of Local Communities," in Proceeding of CIB - W110 Meeting and Conference "Sustainable Slum Upgrading in Urban Areas", 2009, pp. 119-134.

[17] IBEC, Comprehensive Assessment System for Building Environmental Efficiency for Urban Development: Technical Manual, Edition To. Tokyo: IBEC, 2007.

[18] Go, "Lokasi Kampung Warna Warni Jodipan Malang," 2016. [Online]. Available: http://wisatasenibudaya.com/lokasi-kampung-warna-warni-malang-jodipan/.

[19] Fatkhurrozi, "Keindahan Kampung Warna Warni di Malang jadi Daya Tarik Wisata," 2017. [Online]. Available: https://www.liputan6.com/lifestyle/read/3041968/keindahan-kampung-warnawarni-di-malang-jadi-daya-tarik-wisata?page $=1$. 
[20] A. B. Sucipto, "Libur Sekolah Kampung Jodipan," 2017. [Online]. Available: https://www.antarafoto.com/bisnis/v1499943305/libur-sekolah-kampung-jodipan.

[21] Chandra, "Colourful Village," 2017. [Online]. Available: http://www.dronestagr.am/colorfulvillage/. 